\section{Vol. 18: 75-81, 2018 \\ ETHICS IN SCIENCE AND ENVIRONMENTAL POLITICS \\ Ethics Sci Environ Polit}

\title{
European efforts to make marine data more accessible
}

\author{
Iain Shepherd
}

\author{
Directorate General for Maritime Affairs and Fisheries, European Commission, 1049 Bruxelles/Brussel, Belgium
}

\begin{abstract}
Marine data are held by hundreds of different institutions in Europe: hydrographic offices, geological surveys, local authorities, environmental agencies, research institutes and universities. The increasing prevalence of open data policies helps to make these data more accessible and usable. But, on its own, this is not enough. The European Union is therefore supporting a partnership of approximately 150 organisations who are rendering the data more interoperable and therefore more usable through common standards, nomenclature and baselines. The data are accompanied by confidence intervals. This change is already increasing productivity, stimulating innovation, and reducing uncertainty in the blue economy.
\end{abstract}

KEY WORDS: EMODNet $\cdot$ Accessibility $\cdot$ Marine data $\cdot$ Blue ocean

\section{NEED FOR MARINE DATA}

Seas and oceans can provide the stimulus needed to get economies moving. They can provide challenging, rewarding jobs that meet the expectations of our young people. They can provide the clean energy we need if we are to avoid a climate catastrophe. They can provide protein for healthy diets. They can provide pharmaceuticals or enzymes from organisms that inhabit the greatest extremes of temperature, light, and pressure encountered by life. There is also a growing global hunger for raw materials that is increasing the economic attractiveness of deep-sea mining. According to a recent report (OECD 2016, p. 13),

Looking to 2030, many ocean-based industries have the potential to outperform the growth of the global economy as a whole, both in terms of value added and employment. The projections suggest that between 2010 and 2030 on a 'business-as-usual' scenario basis, the ocean economy could more than double its contribution to global value added, reaching over USD 3 trillion.

These new opportunities for blue growth — the long term strategy adopted by an increasing number of countries to support sustainable growth in the marine and maritime sectors as a whole - and jobs are being

${ }^{*}$ Corresponding author: iain.shepherd@ec.europa.eu driven by 2 developments. First, a shortage of available land and freshwater is encouraging mankind to look again at the $71 \%$ of the planet covered by saltwater. Second, rapid advances in underwater observation, remote handling, and construction technology, developed primarily in the petroleum industry, now allow safe operations in deeper waters under a wider range of oceanographic and meteorological conditions.

In some sectors, the growth is already happening. For instance, wind energy is the fastest-growing form of electricity generation in terms of installed capacity. In 2016, $12 \%$ of new installations in Europe were offshore (WindEurope 2017), and this proportion is growing. The industry association's central scenario (European Wind Energy Association 2015) suggests that wind energy will produce $24 \%$ of Europe's electricity by 2030 , with $31 \%$ of this offshore. Success breeds success. Investments such as electricity grids for these offshore wind platforms will bring growth to other industries in their wake.

However, working at this new frontier will inevitably be costlier and riskier than operating on land if each offshore facility needs to construct its own ancillary services such as cabling or supply networks. Costs will also increase if all operators are

( ) The author 2018. Open Access under Creative Commons by Attribution Licence. Use, distribution and reproduction are unrestricted. Authors and original publication must be credited. 
obliged to carry out separate surveys of the sea bottom, measure tide and currents, assess marine life that might be disturbed by their activity, and monitor risks from tsunamis, storms or dangerous marine life.

For instance, aquaculture operators need warnings of approaching toxic algal blooms or jellyfish invasions. Mining companies need to know the topography and geology of the seafloor. Insurance companies and investors in ports and tourism need data on past extreme events to estimate the likelihood of future damage and to develop climate-proof coastal infrastructure. Biotechnology companies looking for new pharmaceuticals or enzymes to catalyse industrial processes need to know where to look for the exotic life forms that can live without light or withstand extremes of temperature.

Marine knowledge is needed in the licencing, design, construction, and operation of offshore installations. A leading licensee of offshore wind energy has argued (Marine Observation and Data Expert Group 2011) that marine data should be a public good; that business could be more competitive and the cost of generating offshore energy could be cut if there were clearer public policies on data ownership, less costrecovery pricing from public bodies, and common standards across jurisdictions and disciplines.

Since 'even an entire society, a nation, or all simultaneously existing societies taken together, are not owners of the Earth. They are simply its possessors, its beneficiaries, and have to bequeath it in an improved state to succeeding generations' (Marx 1894 , p. 567), this new marine economy needs to be sustainable. Offshore operators need marine knowledge to assess and limit the environmental impact of any proposed activity.

\section{Public authorities}

Coastal authorities need knowledge of erosion rates, sediment transport and topography to determine whether protection, accommodation or retreat is the most appropriate strategy for managing shorelines. Fisheries authorities need data on past effort and catch composition to set quotas for the following year. Public health authorities need to assess whether the sea is safe for bathing and seafood safe to eat. Civil protection authorities need to be able to calculate where an oil spill will hit the shore. Coastguards need to know how long survivors of an accident can survive in the water. Environmental authorities need to assess the environmental status of their seas and oceans and to ensure they remain safe and clean (Eu- ropean Parliament and Council 2008). The achievement of EU goals on integrated coastal zone management (European Parliament and Council 2002) and maritime spatial planning (European Parliament and Council 2014) requires knowledge of human activities and sensitive habitats. Maritime surveillance by radar or sonar is improved with knowledge of seasurface conditions, temperature, and salinity.

\section{Science}

Scientific understanding underpins industrial innovation and environmental protection.

Marine science depends on observations. We cannot run controlled experiments with 2 planet Earths. Only by looking back at the past can we understand what might happen in the future. Gaps left in the record cannot be filled later. According to Nature, '(...) an accurate and reliable record of what is going on can trump any particular strategy for trying to understand it' (Editorial 2007, p. 761).

With these observations, scientists can begin to reduce uncertainty about the past and present behaviour of processes such as ocean circulation, ice melting, sea-level rise, carbon uptake, ecosystem shifts, or ocean acidification - all of which have significant impacts on human well-being and natural ecosystems. Climate change has triggered human migrations in the past and will no doubt be a factor in the future (Reuveny 2007). Better monitoring of the seas and oceans is not sufficient to reduce this uncertainty, but it is certainly necessary. The Economist (Editorial 2012) has suggested that governments are not spending enough on satellite observations.

Reducing uncertainty in the past and present can improve forecasts for Europe's climate that are fed into the review and assessment process of the Intergovernmental Panel on Climate Change (IPCC). Wide international participation and careful peerreview ensure that the Panel's assessments are the main vehicle for informing government officials responsible for introducing adaptation measures.

\section{Civil society}

Citizens in a democracy need information to hold their elected representatives to account on issues that affect their neighbourhood, their livelihoods, their health, or the planet Earth that they wish to bequeath to their children. Experience has shown it is wrong to assume that the technical background to 
these issues is best left entirely to the appropriate responsible authorities. An inquiry into the late reaction to the BSE crisis in Britain that led to unnecessary spreading of infection to humans concluded that government action had been influenced by a political need to reassure the public about the safety of British beef (Opinion 2000). According to Sir Robert May, the UK's chief scientific advisor (May 2000):

You can see the temptation on occasion to wish to hold the facts close so that you can have internal discussion and the formation of a consensus so that a simple message can be taken out into the market place. My view is strongly that that temptation must be resisted, and that the full messy process whereby scientific understanding is arrived at with all its problems has to be spilled out into the open.

An editorial in Nature (Editorial 2011, p. 135) used the example of the Fukushima accident to make the case that better public access to data would contribute to better risk assessment: 'This would unleash the diverse creativity of academic researchers, journalists, software geeks and mappers'.

\section{THE PROBLEM}

In its 2010 Communication (European Commission 2010), the European Commission pointed out that bottlenecks were preventing investments in marine data from delivering their potential benefits. Data were held by hundreds of different institutions in the EU, including hydrographic offices, geological surveys, local authorities, environmental agencies, research institutes, and universities. Finding out who held the data was a major challenge. Obtaining the data could take weeks of negotiation, and putting them together to provide a complete picture could be a complex and lengthy process. Many data were typically neither accessible nor interoperable.

\section{THE BENEFITS AND CHALLENGES OF A SOLUTION}

Facilitating access and re-use of data has 3 main benefits for the blue economy: more productivity, more innovation, and less uncertainty.

\section{More productivity}

The first of these benefits is quantifiable. An integrated, as opposed to fragmented, approach to mar- ine data can increase efficiency; first, because measurements made once and made available do not need to be repeated and, second, because it costs less to put together marine data with the same standards, baselines, formats, and nomenclature. The United States National Oceanic and Atmospheric Administration (NOAA) have constructed a business case for improving the ocean observing system (Willis 2009). The interviews conducted in developing this case led them to believe that these opportunity costs represent at least $25 \%$ of the cost of using ocean data to generate products and services.

The author of the present paper has developed the following equation to describe the total saving $S^{s}$ to stakeholder group $s$ :

$$
S^{s}=\sum_{i=1, N}\left[\propto_{i}^{s} \beta_{i}^{s}+\left(1-\alpha_{i}^{s}\right) \gamma_{i}\right] \varnothing_{i}^{s} C^{s}
$$

where $C^{s}$ is the total cost of data to stakeholder group $\mathrm{s}$ including the collection of new data and the processing of existing data; $\varnothing_{i}^{s}$ is the fractional contribution of a particular type of data $i$ (geological, physical, chemical, etc.) to the total cost to stakeholder group $s_{;} \alpha_{i}^{S}$ is the proportion of the cost that is due to data that cannot be found and needs to be collected; $\beta_{i}^{S}$ is the proportion of the data that has already been acquired by other stakeholders but that cannot be accessed at present; and $\gamma_{i}$ is the savings in processing existing data because they are accessible, catalogued, and standardised expressed as a proportion of the total cost.

A back-of-envelope estimate by the services of the European Commission (European Commission 2014) revealed that potential annual gains within the European Union could be in the order of a billion euro per year.

\section{More innovation}

The second of these benefits is harder to quantify but is nevertheless real. When data are fragmented, only the holders of data can provide added value services. Opening up the data allows many more providers to offer services. Competition alone can spur innovation (Aghion et al. 2005). The range of services that can be provided is also increased because it becomes feasible to offer services based on data from more than one source.

A classic example is fish-stock assessment. Standard practice is for all those nations fishing a particular area to send representatives to a week-long meeting, bringing data on catch and effort by their vessels to the table. If the data were more readily available, 
the market would be open to new ideas from universities or small companies. Different viewpoints can also provide more robust solutions (McNutt 2014, Saltelli \& Giampietro 2017).

\section{Less uncertainty}

Better data means better knowledge of what is going on, what has happened and what might happen in the future.

Intuitively, one can understand the cost saving from reduced uncertainty. For instance, the International Panel for Climate Change (IPCC) fifth assessment report (IPCC 2013) gives ranges of potential sea level rise by 2100 of $\pm 20 \mathrm{~cm}$ with the same assumptions of greenhouse gas concentrations. Narrowing this uncertainty would certainly reduce the cost of coastal defence work, but quantitative analyses of the benefits are hard to find. Better knowledge of seabed topography can also contribute to the maritime economy. NOAA estimated that certainty over one additional foot of draught (depth of a vessel's keel below the waterline) would lead to an increased profit per transit to Tampa estimated between USD $\$ 36000$ and $\$ 288000$ (NOAA 2000).

\section{Challenges}

The main challenges to making data more available are making sure that the data and data products are properly labelled with how they were gathered-place, date and instrument used-and ownership. Providers of data are more inclined to provide data if they know that the data will be properly recognised. A moratorium of 2 or $3 \mathrm{yr}$ can be included with scientific data to allow the scientist concerned to publish the results. Initially, some public agencies such as hydrographic agencies that were partly funded by income derived from their monopoly position as providers of navigational charts were reluctant to provide data. This is still partly the case but there has been progress. As studies were published showing the economic benefits of sharing (PriceWaterhouseCooper 2008) and as it became clearer that the use of this data was wider than for purely navigation, the spatial resolution of data that they were prepared to release has become finer.

\section{THE SOLUTION}

To provide a more integrated approach to marine data, the EU embarked upon the construction of a European Marine Observation and Data Network (EMODnet, http://emodnet.eu; Fig. 1). The basic principle is that marine data should be maintained by organisations that collect or own the data but accessed in a common way. This means that a user would be able to search for, visualize, and retrieve all the measurements concerning a specific parameter within a certain time and space window with one single command wherever the data are stored. To maximise innovation and minimise bureaucracy, marine data should be free of charge and free of restrictions on use. Key features of EMODnet, which is being developed by a partnership of >100 organisations, are the following:

- EMODnet does not deal with data from Earthorbiting satellites or fisheries surveys. These are dealt with by other EU programmes which are increasingly integrated with EMODnet.

- In addition to the data that participating organisations make available from their own and other repositories through EMODnet, they are creating data products and information services and making

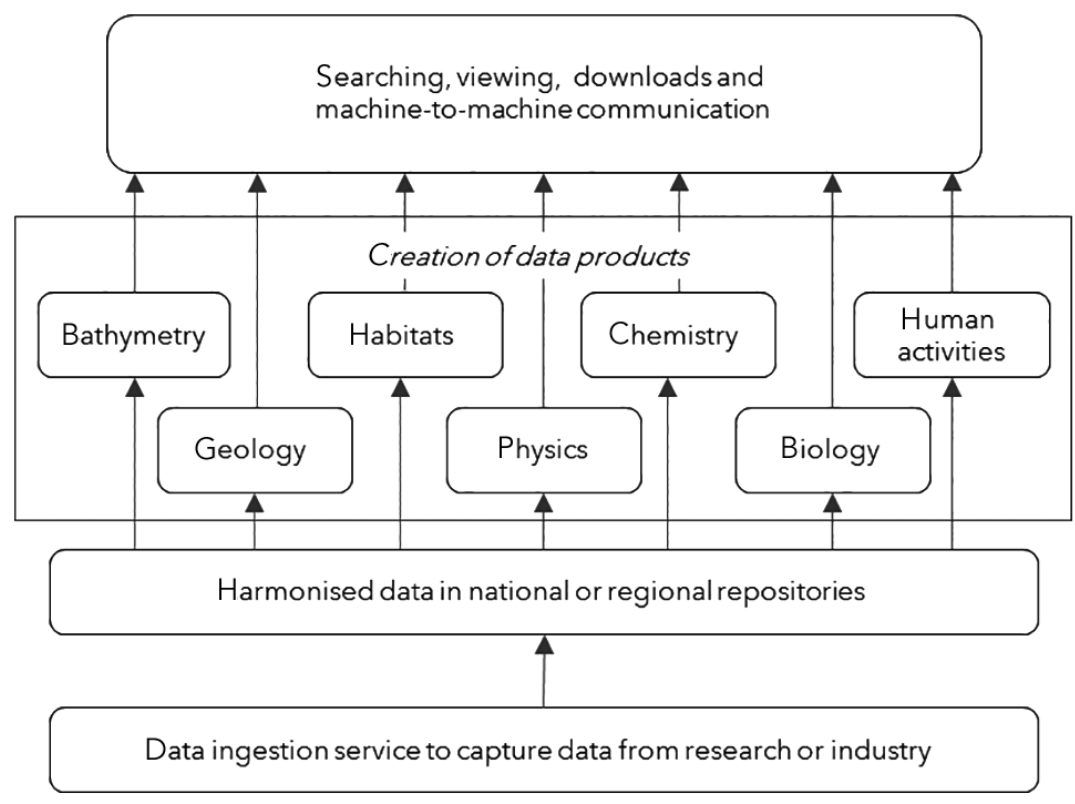

Fig. 1 simplified diagram of main elements of European Marine Observation and Data Network (EMODnet) 
them available. Data products are derived from the raw data but are not confined to single points in space and time. These data products are not designed for a specific purpose but rather serve many needs. Examples include digital terrain models (three-dimensional representations of the shape of the sea bottom) or sediment map layers. It would be inefficient if everybody who needed a digital terrain model had to construct one from original surveys: considerable effort is required to create these products by knitting together data from many different sources, ensuring continuity and coherence across borders and across different disciplines.

- It is a fundamental principle of EMODnet that data and data products should be accompanied by an indication of their origin and ownership in order that the work of the organisations that collect and process the data be recognised in compliance with the INSPIRE Directive (European Parliament and Council 2007) and applicable implementing rules when appropriate. Wherever possible, there should be indications of accuracy and precision. For instance, the digital terrain model provides not only the average water depth over a given area but also the standard deviation.

- EMODnet is divided into 7 thematic groups: geology; bathymetry, physical habitats, physics, chemistry, biology, and human activity. Each thematic group is a partnership of organisations that have the necessary skills and access to data to standardise the presentation of data and create data products. For instance, the partners of the thematic group for geology are bodies responsible for geological surveys in EU coastal states as well as a number of neighbouring states. The group on human activities started later than the others but has proved particularly useful for estimating cumulative impacts (Halpern et al. 2015) as required for EU legislation such as that for marine spatial planning (European Parliament and Council 2014) or the Marine Strategy Framework Directive (European Parliament and Council 2008). These include not only the position and nature of features related to present economic activity such as aquaculture cages, oil and gas boreholes, shipping lanes, pipelines, and cables but also features of the past that need protecting such as shipwrecks or submerged Palaeolithic settlements.

These principles were endorsed by public and private stakeholders following a public consultation 'Marine Knowledge 2020', launched by a Green Paper (European Commission 2012). As a result of the consultation, 2 new features were added:
(1) To provide a common gateway to the thematic groups, an entry portal has been built providing map catalogues and search features.

(2) From the beginning of 2017, a data ingestion facility has been in operation. This includes a help desk that helps data holders whose data would otherwise be lost to provide their data for safekeeping and dissemination. It is particularly targeted at researchers and private companies.

\section{EVALUATION}

EMODnet and its sister initiatives have made a difference. For instance, civil engineering companies assessing tsunami risk or planning port facilities have already reported that EMODnet is improving performance (EMODnet Secretariat 2017a).

In total, 34 data providers from 19 countries provided components for EMODnet's topographical map of the EU's seas. When the UK Meteorological Office replaced the topographic map that they had originally used with this 'EMODnet' map, the accuracy of their storm surge forecasts in the North Sea improved massively. This area is particularly vulnerable to flooding as shown in the catastrophe in 1953, and it is expected that the severity and frequency of such events will increase in the future (Vousdoukas 2016). Some work is ongoing to estimate the value to life and property of such reduction in uncertainty but it will almost certainly be an underestimate because it will be based on a sample of known cases. The downside of open data is increased difficulty in knowing how the data are used. There are almost certainly examples of other disadvantages.

There is still a long way to go. Stelios Katsanevakis (2017) and others report that lack of reliable data impedes the achievement of marine conservation efforts.

To obtain a more precise idea of gaps in data, either caused by access difficulties or because the data had not been collected, teams of researchers were asked to put the data through a series of 'stress tests' (European Commission 2017). Each team, chosen through separate calls for tender for each European sea-basin-Arctic, Atlantic, Baltic, Black Sea, North Sea and Mediterranean-were entrusted with the tasks. The composition of the teams varied. Some were largely public bodies; others were private consultancies.

The tests involved asking questions such as determining whether the marine protected areas in each sea basin constituted a coherent network, assessing 
how suitable a particular site was for siting a wind farm, or determining how well the progression of an oil slick could be forecast. This was not an exercise of wise experts sitting round a table. Rather these were practical exercises with maps, tables and spreadsheets as output. They were required to summarise results in data adequacy reports, check them with panels of stakeholders from the public and private sectors and disseminate them through a website (EMODnet Secretariat 2017b).

The exercise confirmed that whilst efforts such as EMODnet have made a difference, many data are still hidden, unavailable, or mutually incompatible. Whilst some results were expected - for instance the difficulty in finding time series longer than $50 \mathrm{yr}$ for measuring climate change - others were more of a surprise. Despite the ubiquitous use of GPS tracking and electronic reporting devices, it is hard to obtain reliable information on fisheries activity and its impact on the environment. The interface between land and sea proved particularly troublesome. Measurements of European river discharges, sediment movement, and coastal erosion are scattered and not available in common formats. Given that most economic activity is in these areas and given the uniqueness and value of the ecosystems there, efforts have begun to tackle these parameters.

Furthermore, there is general concern that whilst access to marine data is improving, budget restrictions are threatening the maintenance of a number of the long-term marine observation programmes that deliver these data. Awareness of the considerable benefits that they provide to the economy and society in general needs to be spread more widely.

Acknowledgements. This article includes insights gained and lessons learned by the services of the European Commission in the preparation and implementation of measures to improve availability and usability of marine data, some of which were reported in the original proposal for a European Marine Observation and Data Network (European Commission 2010), the Green Paper public consultation (European Commission 2012) and the roadmap (European Commission 2014).

\section{LITERATURE CITED}

Aghion P, Bloom N, Blundell R, Griffith R, Howitt P (2005) Competition and innovation: an inverted-U. Q J Econ 120:701-728

Halpern BS, Frazier M, Potapenko J, Casey KS and others (2015) Spatial and temporal changes in cumulative human impacts on the world's ocean. Nat Commun 6: 7615

Editorial (2007) Patching together a world view. Nature 450: 761
Editorial (2011) A little knowledge. Nature 472:135

Editorial (2012) Something to watch over us. Economist May 2012

EMODnet Secretariat (2017a) EMODnet bathymetry data supporting IMDC consultants in tackling waterrelated issues. http://emodnet.eu/emodnet-bathymetrydata-supporting-imdc-consultants-tackling-water-relatedissues (accessed 2 December 2017)

EMODnet Secretariat (2017b) Sea basin checkpoints. http:// emodnet.eu/checkpoints (Accessed 16 December 2017)

European Commission (2010) Marine Knowledge 2020 marine data and observation for smart and sustainable growth. Commission Communication COM(2010) 461, Publications Office of the European Union, Luxembourg

European Commission (2012) Marine Knowledge 2020 from seabed mapping to ocean forecasting. Green Paper, Publications Office of the European Union, Luxembourg

European Commission (2014) Marine Knowledge 2020: roadmap accompanying the document 'Innovation in the Blue Economy realising the potential of our seas and oceans for jobs and growth'. Commission SWD/2014/ 0149, Publications Office of the European Union, Luxembourg

European Commission (2017) Are Europe's marine data fit for purpose? - outcome of stress tests. https://webgate.ec. europa.eu/maritimeforum/en/node/4024

European Parliament and Council (2002) Recommendation of the European Parliament and of the Council of 30 May 2002 concerning the implementation of Integrated Coastal Zone Management in Europe. Off J Eur Union L $148,6.6 .2002$, p $24-27$

European Parliament and Council (2007) Directive 2007/ 2/EC of the European Parliament and of the Council of 14 March 2007 establishing an infrastructure for spatial information in the European Community. Off $\mathrm{J}$ Eur Union L 108, 25.4.2007, p 1-14

European Parliament and Council (2008) Directive 2008/56/ EC of the European Parliament and of the Council of 17 June 2008 establishing a framework for community action in the field of marine environmental policy (Marine Strategy Framework Directive). Off J Eur Union L 164, 25.6.2008, p 19-40

European Parliament and Council (2014) Directive 2014/89/ EU of the European Parliament and of the Council of 23 July 2014 establishing a framework for maritime spatial planning. Off J Eur Union L 257, 28.8.2014, p 135-145

European Wind Energy Association (2015) Wind energy scenarios for 2030: a report by the Wind Energy Association, August 2015

IPCC (2013) Climate Change 2013: the physical science basis. Contribution of Working Group I to the Fifth Assessment Report of the Intergovernmental Panel on Climate Change (Stocker TF, Qin D, Plattner GK, Tignor M et al., eds) Cambridge University Press, New York, NY

Marine Observation and Data Expert Group (2011) Proc Twelfth meeting of Marine Observation and Data Expert Group. 10 Mar 2011, Brussels. https://webgate.ec.europa. eu/maritimeforum/node/1709

Marx K (1894) Part VI. Transformation of surplus-profit into ground-rent. In: Engels F (ed) Capital: A critique of political economy. Volume III: The process of capitalist production as a whole. International Publishers, New York, NY

May SR (2000) The BSE enquiry. http://webarchive.national 
archives.gov.uk/20060715141954/http:/bseinquiry.gov.uk/ report/volume1/chapt142.htm\#648953 (accessed 5 June 2017)

McNutt M (2014) Reproducibility. Science 343:229

NOAA (2000) National Physical Oceanographic Real-Time Systems (PORTS) Management Report. NOAA, Silver Spring, MD

OECD (2016) The ocean economy in 2030. OECD Publishing, Paris

Opinion (2000) Following through on Phillips. Nature 408:1

PriceWaterhouseCooper (2008) INFOMAR Marine Mapping Study-Options Appraisal Report: Final Report. Economics and public policy

Reuveny R (2007) Climate change-induced migration and violent conflict. Polit Geogr 26:656-673

Editorial responsibility: Konstantinos Stergiou, Thessaloniki, Greece
Saltelli A, Giampietro M (2017) What is wrong with evidence based policy, and how can it be improved? Futures 91:62-71

Stelios Katsanevakis PM (2017) Advancing marine conservation in European and contiguous seas with the MarCons Action. Research Ideas and Outcomes 3:e11884

* Vousdoukas M (2016) 'Projections of extreme storm surge levels along Europe' Climate Dynamics. Clim Dyn 47: 3171-3190

Willis Z (2009) The business case for improving NOAA's management and integration of ocean and coastal data. NOAA IOOS Programme

WindEurope (2017) Wind in power: 2016 European statistics. https://windeurope.org/wp-content/uploads/files/aboutwind/statistics/WindEurope-Annual-Statistics-2016.pdf

Submitted: August 1, 2017; Accepted: February 19, 2018

Proofs received from author(s): July 30, 2018 